\title{
Screening for Prostate Specific Antigen in Various Types of Breast Tumor
}

\author{
A.S.A. El-Bayoumy ${ }^{1}$, M. Fawzy, A.B. Abdel-Ghaffar ${ }^{2}$ and A. Osman ${ }^{2}$. \\ ${ }^{1}$ Labelled Compounds Department, Hot Laboratories Center, Atomic Energy Authority \\ and ${ }^{2}$ Biochemistry Department, Faculty of Science, Ain Shams University.
}

\begin{abstract}
$\mathbf{T}$ HE OBJECTIVE of the present study is to investigate a comparative estimation screening method of prostate specific antigen levels in serum samples with immunohistochemistry results for analysis expression of prostate specific antigen in female breast tissues at benign breast hyperplasia and breast cancer. This study was applied on 65 women suffering from breast cancer, 31 of them have benign breast hyperplasia and 34 have malignant breast cancer. Each group was divided into 2 subgroups, pre and postmenopause, both subgroups were compared with 15 normal cases to assess serum and tissue PSA in benign and malignant patients in pre and post menopause state by immunoradiometricassay in blood and immunohistochemistry in tissue. No significant difference in serum Total PSA concentration between any of the studied cases was observed. However, there were different variations in the distribution of PSA in the breast tumor tissue, with complete absence of PSA in the tissue samples of the malignant in postmenopausal patients. In conclusion, PSA presence in benign breast hyperplasia in either serum or tissue may show a clinical value regarding the diagnosis and prognosis of the disease.
\end{abstract}

Keywords: Prostate Specific Antigen, Breast Tumor, CA 15-3, Immunohistochemistry.

\section{Introduction}

Proteins that are expressed by both malignant and healthy fetal tissues are recognized as oncofetal. These antigens are associated with cell proliferation and differentiation and are produced in high concentrations in pregnancy and malignancy. Their biological role in malignancy is the suppression of the host's immune system, while in pregnancy they affect the maternal immune response, generating maternal tolerance toward the embryo. The levels of alpha-fetoprotein (AFP), human chorionic gonadotropin (hCG), carcinoembryonic antigen (CEA), cancer antigen 125 (CA 125), squamous cell carcinoma antigen (SCC), cancer antigen 15-3 (CA 15-3), mucinlike carcinoma-associated antigen (MCA), tissue polypeptide-specific antigen (TPS), carbohydrate antigen 19-9 (CA 19-9), and prostate-specific antigen (PSA) in maternal serum (MS), umbilical cord serum (UC), and amniotic fluid (AF) have different roles in the assessment of pregnancy and malignancy. All these antigens, except CA 15-3, are oncofetal. The presence of considerable concentrations of AFP, hCG, CEA, CA125, SCC, MCA, TPS, CA 19-9, and PSA in AF during pregnancy may be attributed to their involvement inbiological functions associated with fetal development, differentiation, and maturation. MS CEA,CA 15-3, and CA 19-9, in contrast to all the others, are not influenced significantly by pregnancyand thus remain reliable tumor markers in monitoring malignancy in pregnant patients, $(\mathrm{Yu}$ and Berkel 1999, Sarandakou, Protonotariou et al. 2007).

To date, no true tissue specific antigen has been discovered. Prostate-specific antigen (PSA) was initially reported to be a tissue specific protein. The name prostate-specific antigen has been given to a protein that now is known not to be prostatespecific. PSA detected in the seminal fluidand produced by normal and abnormal epithelial cells of the prostate gland. PSA is a $33 \mathrm{kDglycoprotein}$, with serine protease activity, seminal plasma contains about 1 millionmicrograms/L of PSA and is the richest source of PSA reported, and it is produced by various tissues in the human body. Its expression levels may be elevated during benign 
andneoplastic cell growth in the prostate and in a number of other human malignancies. Male serumPSA is usually less than 4 micrograms/L. In nonprostatic tissues, PSA exists mainly in its freemolecular form, but PSA-ACT complex is also present in most of the fluids that contain PSA, such as breast secretions and amniotic fluid. The detection of PSA is also useful in monitoringthe efficacy of anticancer treatment in malignant prostatic adenocarcinoma,(Borchert, Melegos et al. 1997, Diamandis and Yu 1997).

Prostate-specific antigen (PSA) was recently found in $30 \%$ of female breast tumors. PSA hasbeen shown to be expressed in many forms of female tissues. The breast is a major female organ that isable to produce PSA (Yu and Berkel 1999, Kamenov, Todorova et al. 2001). PSA is detected in bothnormal and abnormal breast tissues, as well as in various breast fluids including milk, nippleaspirate, and cyst fluid. The biologic fluid with the second highest PSA concentration, however, is nipple aspirate fluid from the female breast (up to about 5000 micrograms/L), and the third ismilk from lactating women (up to 300 micrograms/L). Androgens and progesterone, via theirreceptors, regulate the production of PSA in breast tissue. Clinical studies demonstrate that PSAin breast cancer is associated with the expression of estrogen receptor and progesterone receptor.

Women with PSA-positive breast cancer have better disease-free survival as well as overallsurvival than those with PSA-negative breast cancer. PSA levels in nipple aspirate fluid may beindicative of breast cancer risk. High concentrations of PSA are found in amniotic fluid and thelevels change with gestational age (Mitchell, Sibley et al. 2002, Narita, Cimpean et al. 2006). Pregnant womenhave elevated serum PSA. PSA levels in serum also vary during menstrual cycles and increase inwomen with excess androgen. Clinical implications of PSA in amniotic fluid and female serumhave been suggested. The immunoexpression of prostatespecific antigen in breast cancers hasbeen well established, but the role of this extra-prostate PSA appears to be a complex, poorlyunderstood and of doubtful prognostic value (Giai, Yu et al. 1995, Mitchell, Sibley et al. 2002, Narita, Cimpean et al. 2006).

The gene expression and protein production of PSA in nonprostatic tissues are under theregulation of steroid hormones via their receptors. Egypt. J. Rad. Sci. Applic., Vol. 30, No.1(2017)
Androgens, glucocorticoids, and progestinsupregulate the PSA gene expression, resulting in an increase of protein production. Estrogen byitself seems to have no effect on PSA regulation, but it can impair PSA production induced byandrogen. It remains unknown whether PSA is enzymatically active and what is the physiologicrole of PSA in nonprostatic tissues. It is speculated that PSA may be involved in the regulation ofgrowth factors (Sauter, Lininger et al., 2004).

A comparative estimation screening method of prostate specific antigen levels in blood serum with immunohistochemistry for analysis expression of prostate specific antigen in female breast tissue at benign breast hyperplasia and breast cancer isthe aim of this study.

\section{Subjects and methods}

Subject

A total of 65 Egyptian women aged 30-69 years were recruited for this study and selected from outpatient's clinic at the National Cancer Institute. Physical examinations were processed by physicians in the Medical Oncology Unit and routine clinical examination was further demanded for diagnosis. The patients were grouped according to their clinical status into 4 different groups, benign breast hyperplasia premenopause, benign breast hyperplasia postmenopause, breast cancer premenopause and breast cancer postmenopause.

\section{Diagnosis}

After physical examination, patients were forwarded for furtherinvestigations that include complete blood count (CBC), serum Cancer Antigen 15.3 (serum CA 15.3) and prostatic specific antigen (PSA), alkaline phosphatase activity, as well as Calcium. Furthermore, immunohistochemistry examination of prostatic specific antigen was fulfilled for breast biopsies.

\section{Blood collection and sampling}

Venous blood samples were generally collected from patients at the outclinic unit. Each blood sample was divided into two vacutainer labeled tubes, with or without anticoagulant (EDTA). Blood was collected in EDTA used in analysis of complete blood count (CBC).In the other tube, blood was allowed to stand for 1 hour at room temperature and then centrifugated at 5,000 rpm for $5 \mathrm{~min}$ and serum was aspirated and preserved at $-70^{\circ} \mathrm{C}$ for the analysis of Cancer antigen 15-3 (CA 15-3) and prostatic specific antigen (PSA), Alkaline phosphatase and Calcium levels. 


\section{Determination of $C A 15.3$}

CA15.3 was carried out by The AxSYM CA 15-3 assay whichis a Microparticle Enzyme Immunoassay (MEIA) for the quantitative measurement of CA 15-3 values in human serum and plasma (EDTA)(Hayes, Zurawski et al. 1986, Sekine 1987, Shimokata, Totani et al. 1988). The Abbott AxSYM CA 15-3 assay is based on the 115D8 and DF3 antibodies which are available exclusively through Fujirebio, Inc.

\section{PSA in serum}

PSA was determined usingPSA IRMA Kit supplied by IZOTOP Inc. Ltd. The technology uses two high affinity monoclonal antibodies in an immunoradiometric assay system(Ooi and Escares 1991, Abbate, Musci et al. 1996).

\section{Determination of $\mathrm{Ca}$ in serum}

Calcium ions were determined using SPECTRUM Diagnostics Kit.The reaction based on the Ca reaction with o-cresolphthalein complexone (o-CPC) under alkaline conditions to form a violet colored complex. The addition of 8-hydroxyquinoline prevents interference by magnesium and iron. It was determined by measuring the increase in absorbance at 578 nm, (Kessler and Wolfman 1964).

Determination of Alkaline phosphatase in serum:

Alkaline Phosphatase activity was determined using SPECTRUM Diagnostics
Kit.The reaction wasbased on the conversion of p-Nitrophenyl phosphate to p-Nitrophenol and phosphate by alkaline phosphatase. The increase of absorption at $405 \mathrm{~nm}$ is proportional to the alkaline phosphatase concentration in the sample, (Moss 1982, Moss 1987).

\section{PSA immunohistochemistry}

Benign \& malignanttissue samples were obtained directly at the operating room temperature, kept in ice. Fat \& necrotic tissue were removed and the tissue samples were divided into 3 aliquots and stored at $-80 \mathrm{C}$ until being used, (Narita, Raica et al. 2005).

\section{Results}

This study included a total of 80 cases divided into three major groups. Healthy subjects with no history of any medical or genetic disease (n $=15$ ). The second group consisted of female subjects diagnosed with benign breast cancer by the personal of the National Cancer Institute $(\mathrm{n}=31)$, those were further divided into 2 subgroups according to their menopause status as pre- $(n=19)$ and postmenopause $(n=12)$. The third group consisted of female subjects diagnosed with comprised malignant breast cancer by the personal of the National Cancer Institute $(\mathrm{n}=34)$, those were further divided into 2 subgroups according to their menopausal status as pre $(\mathrm{n}=14)$ and postmenopause $(\mathrm{n}=$ 20), (Table 1).

TABLE 1. Data of the studied subjects.

\begin{tabular}{cccccc}
\hline & $\begin{array}{c}\text { Post- } \\
\text { Menopause }\end{array}$ & $\begin{array}{c}\text { Penign } \\
\text { Menopause }\end{array}$ & $\begin{array}{c}\text { Malignant } \\
\text { Post- } \\
\text { Menopause }\end{array}$ & $\begin{array}{c}\text { Pre- } \\
\text { Menopause }\end{array}$ & Normal \\
\hline Number & 12 & 19 & 20 & 14 & 15 \\
Age (Years) & $52.50 \pm 5.89$ & $30.47 \pm 7.36$ & $58.5 \pm 7.29$ & $39.29 \pm 4.82$ & $43.4 \pm 14.7$ \\
Range & $45-63$ & $17-41$ & $49-75$ & $30-45$ & $19-63$ \\
Data are shown as mean \pm SD. & & & & \\
\hline
\end{tabular}

Figure 1 shows serum Calcium concentration and Alkaline Phosphatase activity for the studied subjects. Our data showed only a significant difference in serum Calcium concentration between benign breast cancer patients and normal subjects. In addition, the data of the present studydid not found any significant difference in serum Alkaline Phosphatase activity between any of the studied subjects using unpaired " $\mathrm{t}$ " test.

Regarding serum CA-15.3, the data of the present work showed a significant difference in serum CA 15.3 concentrating when comparing benign and malignant patients with normal subjects. Also, there was a significant difference observed when comparing all the subgroups with normal subjects, (Table 2).

Egypt. J. Rad. Sci. Applic., Vol. 30, No.1(2017) 
For the serum PSA, the resultsdid not show any significant difference in serum Total PSA concentration between any of the studied subjects. On the other hand, the histopathologicalimmunostaining results showed different variations in the distribution of PSA in the breast tumor tissue, with a complete absence of the PSA in the tissue samples of the malignant in postmenopausal patients, (Table 3 ).

Figure 2 shows the distribution of the different degrees of positivity of the PSA in the tumor tissues presented as percentage of the total samples studied.

\section{Discussion:}

Breast cancer is a major concern worldwide and is responsible for one of the highest causesofdeath. The chance that breast cancer will be responsible for a woman's death is about 1 in 35 (about 3\%). In 2007, about 40460 women will die from breast cancer in the United States, $1 \%$ of women are diagnostic every year with breast cancer and $85 \%$ are diagnostic with advanced stages of disease (Narita, Anghel et al., 2008).
Researchers are trying to discover new biomarkers for diagnosis, prognosis, treatment monitoring and to develop new drugs that might work better against breast cancer (Narita, Anghel et al., 2010) which may help greatly in early detection of malignancy (Poh, Jayaram et al., 2008). Different factors such as high body mass index, advanced age, family history of breast cancer, a long menstrual history, use of oral contraceptives, exposure to radiation, no childbearing or giving birth to the first child after age 30 are among possible risk factors for breast cancer(Razavi, Ghajarzadeh et al., 2015). Prognostic and predictive markers for breast cancer are a mixture of host factors (e.g., age, menopausal status and inflammatory response) and tumor features (e.g., tumor size, histological grade, nodal involvement, vascular invasion, hormone receptors, growth factors and their receptors, cell proliferation and angiogenesis markers and various DNA or genetic alteration (Porter-Jordan and Lippman 1994).

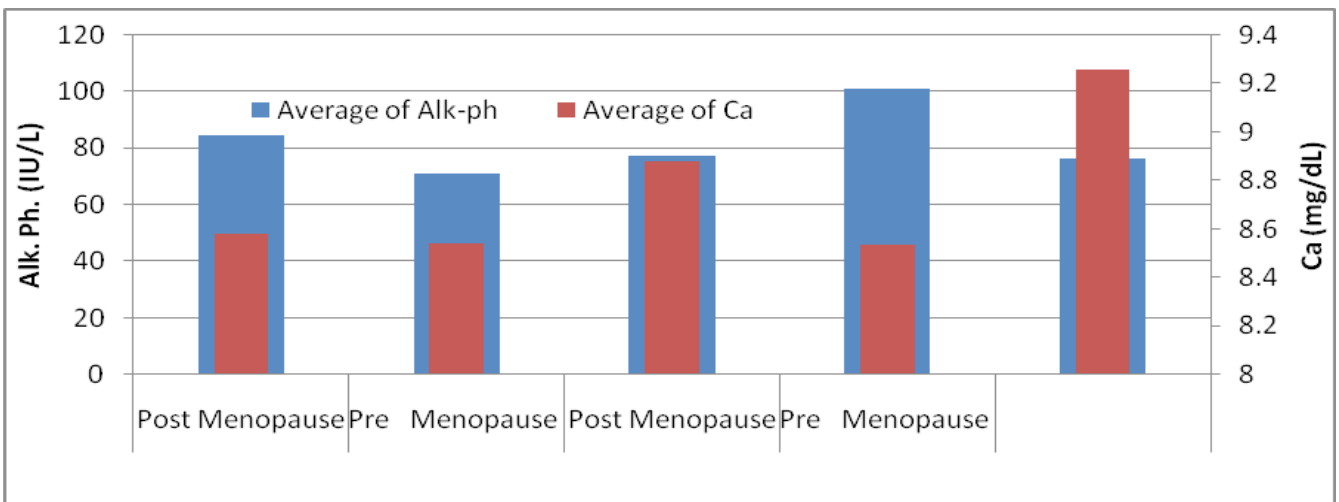

Fig. 1. Comparison of Serum Calcium and alkaline phosphatase in the studied subjects.

TABLE 2. CA-15.3 concentrations in the studied groups.

\begin{tabular}{|c|c|c|c|c|c|}
\hline & \multicolumn{2}{|c|}{ Benign } & \multicolumn{2}{|c|}{ Malignant } & Normal \\
\hline \multirow{3}{*}{$\begin{array}{c}\text { CA- } 15.3(\mathrm{U} / \\
\mathrm{ml})\end{array}$} & \multicolumn{2}{|c|}{$42.84 \pm 8.51^{*}$} & \multicolumn{2}{|c|}{$32.87 \pm 22.53^{*}$} & \\
\hline & Post- Menopause & Pre- Menopause & Post- Menopause & $\begin{array}{c}\text { Pre- } \\
\text { Menopause }\end{array}$ & $\begin{array}{l}19.13 \\
\pm 3.28\end{array}$ \\
\hline & $39.02 \pm 6.13 *$ & $46.66 \pm 8.83 *$ & $38.18 \pm 25.2 *$ & $21.45 \pm 25.48^{*}$ & \\
\hline
\end{tabular}

Data are shown as mean \pm SD.

* p value is significant against Normal subjects.

TABLE 3.Total PSA concentrations in the studied groups.

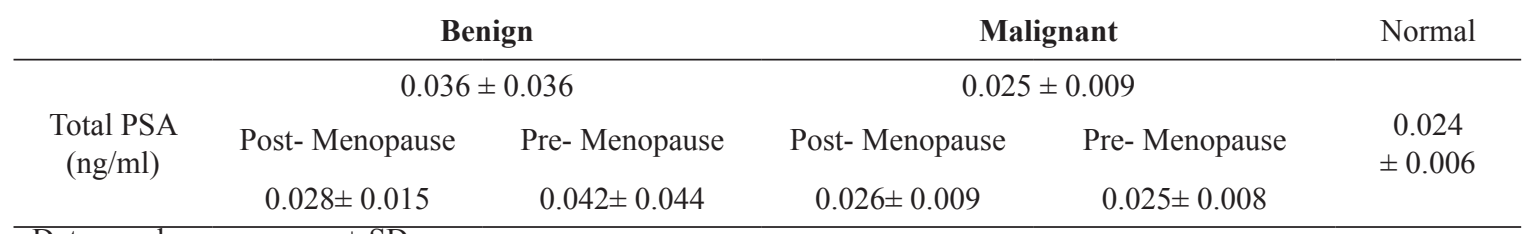

Data are shown as mean \pm SD.

Egypt. J. Rad. Sci. Applic., Vol. 30, No.1(2017) 


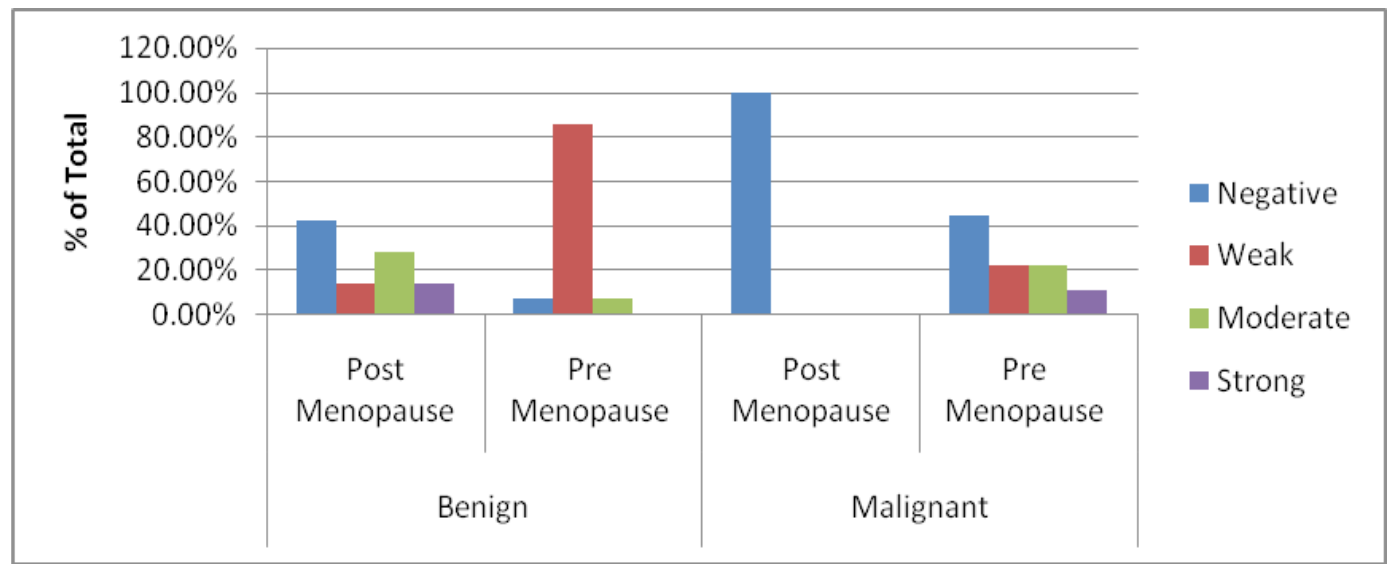

Fig. 2. Distribution of the different grades of PSA positivity in the pathological tissue sections of the different studied patients.
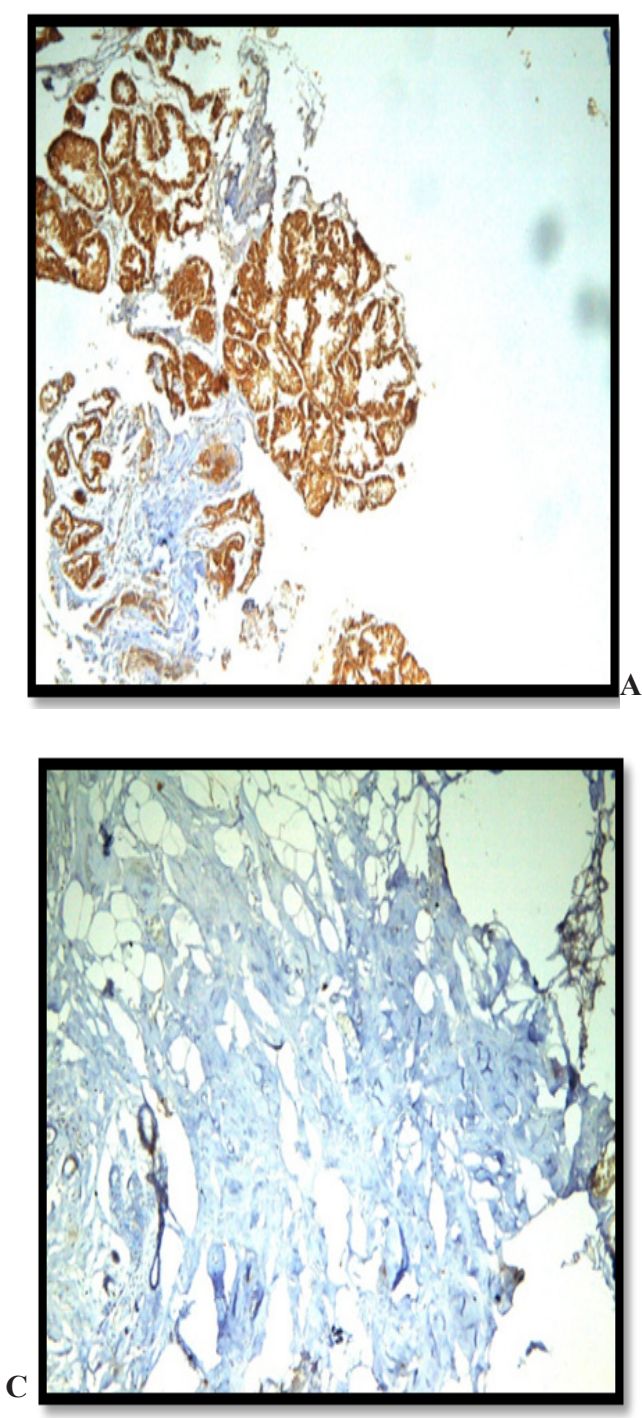
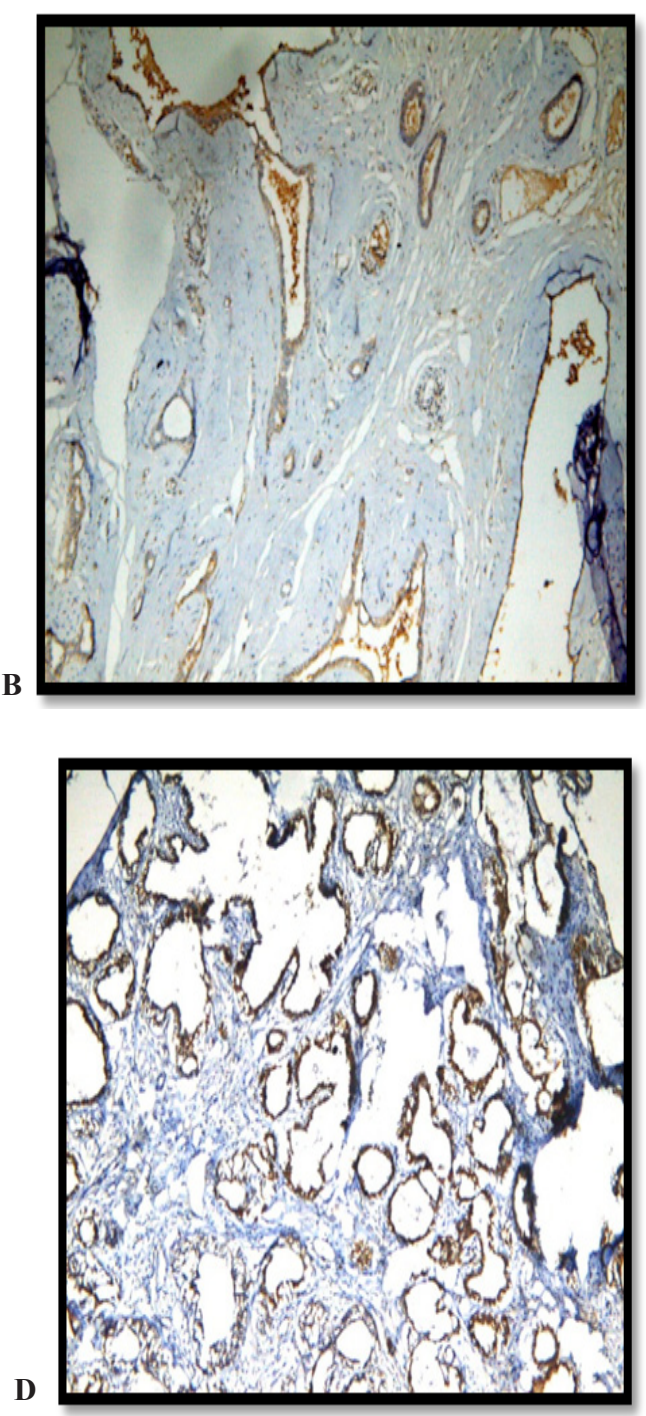

Fig. 3. Immunohistochemical staining of PSA: A- benign postmenopause group, B-benign premenopause group, C-malignant postmenopause group, D-malignant premenopause group (Brown color indicates the presence of PSA). 
Althoughtumor size, axillary lymph node status, and tumor grade are still among the most important prognostic factors (Mohammadizadeh, Ranaee et al., 2012), physicians have difficulty identifying patients who need adjuvant treatment and who will benefit from the treatment because the available markers are not appreciably sensitive and specific. The ultimate goal of using prognostic and predictive markers is to allow physicians to accurately differentiate patients who need postsurgical treatment and to appropriately tailor therapy to their specific needs (Giai, Yu et al. 1995) and decide whether and how to treat breast cancer patients after a local surgery with asignificant impact on survival of patients and health care cost (Elledge, McGuire et al., 1992).

This study aimed to investigate a comparative estimation screening method of prostate specific antigen levels in blood serum with immunohistochemistry results for analysis expression of prostate specific antigen in female breast tissue at benign breast hyperplasia and breast cancer.

CA15-3 was a high-molecular-mass mucinlike glycoprotein expressed at the luminal surface of most secretary epithelia and associated with mammary tumors.Clinical uses of this marker include monitoring of patients with breast cancer, prognosis, recurrence and metastasis (Atoum, Nimer et al., 2012). CA15-3 level correlates exclusively with tumor size; higher CA15-3 serum level was found in advanced cancer stages andhigher grades and metastasis (Theriault, Hortobagyi et al., 1989). CA15-3 level increased in $10 \%$ stage I breast cancer disease, $20 \%$ stage II disease, $40 \%$ stage III disease, and $75 \%$ with stage IV disease (Duffy 2006). Elevated levels of this biomarker were detected among certain benign diseases, primary breast carcinoma (Coveney, Geraghty et al., 1995) and in patients with advanced adenocarcinomas (Nicolini and Carpi 2000).

Aging and menopause disturb the hormonal statusamong females and increase the chance of breast cancer development (Pike, Pearce et al., 2004), at the same time, serum CA153 level showed a significant increase within elderly menopause patients with breast cancer (Dehaghani, Ghiam et al., 2007).

In this study, it was found that there was a significant difference in serum CA 15.3 concentrationon comparing benign and malignant

Egypt. J. Rad. Sci. Applic., Vol. 30, No.1(2017) patients with normal subjects.In addition, except for the malignant premenopause group, there was a significant difference on comparing all the subgroups with normal subjects. The previous findings agree with those of Gourevitch(Gourevitch, von Mensdorff-Pouilly et al., 1995).

However, the data obtained disagree with the data of Kumpulainen, Keskikuru et al., 2002 who assessed CA 15.3 pre or post-operation patients with primary breast cancer, and compared it as a prognostic factor to the conventional prognostic factors to evaluate the usefulness of tumor marker CA 15.3. Kumpulainen, Keskikuru et al., 2002 found that this tumor marker, that is determined at the time of primary diagnosis as a prognostic factor in breast cancer, is correlated with more advanced stage, distant metastases, advanced nodal involvement, higher grade, and lower hormone receptor content.

The results obtained showed that there is no significant difference of serum total PSA concentrations between any of the studied subjects, but there is a slight increase in serum PSA of younger female patients with premenopausal benign hyperplasia. This resultagrees with that of Giai et al. who found that there is no substantial difference between serum PSA levels from normal women and women with breast cancer.

On the contrary, the results disagree with those ofRasavi et al. who found that total and free PSA levels are significantly higher in women with malignant breast masses compared with women who had benign breast masses.

\section{Conclusion}

With PSA distributed in pre and postmenuposal females with benign and malignant breast tissue, it was found that PSA is absent only in postmenupausal females with malignant breast tissue.

\section{References}

Abbate, I., M. D. Musci, A. Paradiso, F. Schittulli, and Correale,M. (1996) "Determination of free PSA in breast cancer cytosols by IRMA." Int J Biol Markers11(1), 53-54.

Atoum, M., N. Nimer, S. Abdeldayem, and H. Nasr (2012) "Relationships among serum CA15-3 tumor marker, TNM staging, and estrogen and progesterone receptor expression in benign and malignant breast lesions." Asian Pac J. Cancer Prev 13(3), 857-860. 
Borchert, G. H., D. N. Melegos, G. Tomlinson, M. Giai, R. Roagna, R. Ponzone, L. Sgro and E. P. Diamandis (1997) "Molecular forms of prostatespecific antigen in the serum of women with benign and malignant breast diseases." $B r J$. Cancer 76(8), 1087-1094.

Coveney, E. C., J. G. Geraghty, F. Sherry, E. W. McDermott, J. J. Fennelly, N. J. O’Higgins and M. J. Duffy (1995) "The clinical value of CEA and CA 15-3 in breast cancer management." Int J. Biol Markers10(1), 35-41.

Dehaghani, A. S., A. F. Ghiam, M. Hosseini, S. Mansouri and A. Ghaderi (2007) "Factors influencing serum concentration of CA125 and CA15-3 in Iranian healthy postmenopausal women." Pathol Oncol $\operatorname{Res13}(4), 360-364$.

Diamandis, E. P. and H. Yu (1997) "Nonprostatic sources of prostate-specific antigen." Urol Clin North Am 24(2), 275-282.

Duffy, M. J. (2006) "Serum tumor markers in breast cancer: are they of clinical value?" Clin Chem52(3), 345-351.

Elledge, R. M., W. L. McGuire and C. K. Osborne (1992) "Prognostic factors in breast cancer." Semin Oncol19(3), 244-253.

Giai, M., H. Yu, R. Roagna, R. Ponzone, D. Katsaros, M. A. Levesque and E. P. Diamandis (1995) "Prostate-specific antigen in serum of women with breast cancer." Br J Cancer72(3), 728-731.

Gourevitch, M. M., S. von Mensdorff-Pouilly, S. V. Litvinov, P. Kenemans, G. J. van Kamp, A. A. Verstraeten and J. Hilgers (1995) "Polymorphic epithelial mucin (MUC-1)-containing circulating immune complexes in carcinoma patients." $\mathrm{Br} J$ Cancer72(4), 934-938.

Hayes, D. F., V. R. Zurawski, Jr. and D. W. Kufe (1986) "Comparison of circulating CA15-3 and carcinoembryonic antigen levels in patients with breast cancer." J Clin Oncol4(10), 1542-1550.

Kamenov, Z., M. Todorova and V. Khristov (2001). "[Prostate-specific antigen (PSA) in women]." Vutr Boles 33(1), 40-47.

Kessler, G. and M. Wolfman (1964) "An Automated Procedure for the Simultaneous Determination of Calcium and Phosphorus." Clin Chem10, 686-703.

Kumpulainen, E. J., R. J. Keskikuru and R. T. Johansson (2002) "Serum tumor marker CA 15.3 and stage are the two most powerful predictors of survival in primary breast cancer." Breast Cancer Res Treat 76(2), 95-102.

Mitchell, G., P. E. Sibley, A. P. Wilson, E. Sauter, R. A'Hern and R. A. Eeles (2002) "Prostate-specific antigen in nipple aspiration fluid: menstrual cycle variability and correlation with serum prostatespecific antigen." Tumour Biol 23(5), 287-297.

Mohammadizadeh, F., M. Ranaee, M. H. Zavareh, M. Faghihi, M. Saremi and M. Eftekhari (2012)"The expression of prostate-specific antigen in invasive breast carcinoma and its relationship with routine clinicopathologic parameters." $A d v$ Biomed Res1,55.

Moss, D. W. (1982) “Alkaline phosphatase isoenzymes." Clin Chem 28(10), 2007-2016.

Moss, D.W. (1987) "Diagnostic aspects of alkaline phosphatase and its isoenzymes." Clin Biochem 20(4), 225-230.

Narita, D., A. Anghel, A. M. Cimpean, D. Izvernariu, N. Cireap, R. Ilina and S. Ursoniu (2010) "Interaction between estrogens and androgen receptor genes microsatellites, prostate-specific antigen and androgen receptor expressions in breast cancer." Neoplasma 57(3), 198-206.

Narita, D., A. Anghel and M. Motoc (2008) "Prostatespecific antigen may serve as a pathological predictor in breast cancer." Rom J Morphol Embryol 49(2),173-180.

Narita, D., A. M. Cimpean, A. Anghel and M. Raica (2006) "Prostate-specific antigen value as a marker in breast cancer.” Neoplasma 53(2), 161-167.

Narita, D., M. Raica, A. Anghel, C. Suciu and A. Cimpean (2005) "Immunohistochemical localization of prostate-specific antigen in benign and malignant breast conditions." Rom J Morphol Embryol 46(1), 41-45.

Nicolini, A. and A. Carpi (2000) "Postoperative follow-up of breast cancer patients: overview and progress in the use of tumor markers." Tumour Biol 21(4),235-248.

Ooi, D. S. and E. A. Escares (1991) “"High-dose hook effect" in IRMA-Count PSA assay of prostatespecific antigen." Clin Chem37(5): 771-772.

Pike, M. C., C.L.Pearce andA. H.Wu (2004)"Prevention of cancers of the breast, endometrium and ovary." Oncogene 23(38), 6379-6391.

Poh, B. H., G. Jayaram, P. Sthaneshwar and C. H. Yip (2008) "Prostate-specific antigen in breast disease." Malays J Pathol 30(1), 43-51.

Porter-Jordan, K. and M. E. Lippman (1994). "Overview of the biologic markers of breast cancer." Hematol Oncol Clin North Am 8(1), 73-100.

Razavi, S. H., M. Ghajarzadeh, A. Abdollahi, S. Shoar and R. Omranipour (2015) "Is Serum Prostatespecific Antigen a Diagnostic Marker for Benign and Malignant Breast Tumors in Women?" Int $J$ Prev Med 6, 15.

Egypt. J. Rad. Sci. Applic., Vol. 30, No.1(2017) 
Sarandakou, A., E. Protonotariou and D. Rizos (2007). "Tumor markers in biological fluids associated with pregnancy.” Crit Rev Clin Lab Sci44(2): 151-178.

Sauter, E. R., J. Lininger, A. Magklara, J. E. Hewett and E. P. Diamandis (2004) "Association of kallikrein expression in nipple aspirate fluid with breast cancer risk." Int J Cancer108(4), 588-591.

Sekine, H. (1987) "[An immunohistochemical study of various breast tissues using CA15-3 (MAb 115D8 and MAb DF3)]." Gan No Rinsho33(8), 913-919.

Shimokata, K., Y. Totani, K. Nakanishi, M. Yamamoto, Y. Hasegawa, H. Kawatsu, H. Sasou, T. Murate, S. Ichiyama, T. Kurasawa and et al. (1988)“Diagnostic value of cancer antigen 15-3 (CA15-3) detected by monoclonal antibodies (115D8 and DF3) in exudative pleural effusions." Eur Respir J1(4),341344.

Theriault, R. L., G. N. Hortobagyi, H. A. Fritsche, D. Frye, R. Martinez and A. U. Buzdar (1989) "The role of serum CEA as a prognostic indicator in stage II and III breast cancer patients treated with adjuvant chemotherapy." Cancer 63(5), 828-835.

Yu, H. and H. Berkel (1999) "Prostate-specific antigen (PSA) in women." J. La State Med Soc. 151(4), 209-213.

(Received 4/4/2017; accepted 30/5/2017)

$$
\begin{aligned}
& \text { فحص دالة أورام البروستاتا فى مختلف انواع أورام الثاى }
\end{aligned}
$$

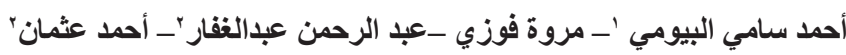

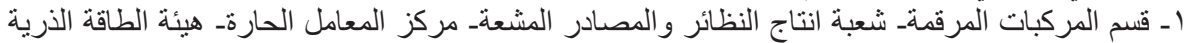

$$
\begin{aligned}
& \text { و r-قسم الكيمياء الحيوية_ كلية العلوم- جامعة عين شمس- مصر. }
\end{aligned}
$$

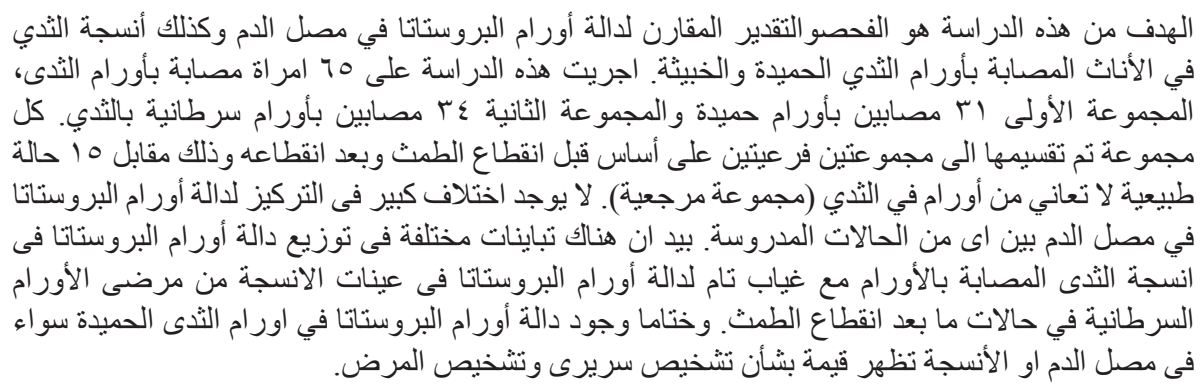

